\title{
Application of Antagonistic Yeasts for Postharvest Disease Control on Chili Fruits
}

\author{
Punika Chaisemsaeng
}

\begin{abstract}
The effective antagonistic yeasts, PFN6 and SS7 isolated from chili field, North East, Thailand. This result based on disease incidence to control Colletotrichum capsici by in vivo test. Both isolates can reduce disease incidence at $5 \times 10^{8}$ cell $/ \mathrm{ml}$ when infected with all spore concentrations of pathogen. The disease incidence on chili fruits could be reducing when treated with high spore concentrations of the pathogen. We found isolate PFN6 at $5 \times 10^{8}$ cells $/ \mathrm{ml}$ showed the best result with $37.27 \%$ of disease incidence at $5 \times 10^{4}$ spores $/ \mathrm{ml}$ of $C$. capsici. These concentrations used to control anthracnose disease on chili fruits. The survival percentage of chili fruit was recorded at 20 days preservation. The result found, antagonistic yeast PFN6 presented the great efficacy of fruit survives with $66.25 \%$. Both of efficacy yeasts were characterized to morphological characteristics. They had white and smooth colony, ovoid shape and single or pairs of cell arrangement. The sequence analysis of D1/D2 domain of 26s ribosomal DNA showed high identity with Candida haemulonii.
\end{abstract}

Keyword--Candida haemulonii, postharvest disease control, anthracnose disease.

\section{INTRODUCTION}

$\mathrm{C}$ HILI (Capsicum spp.) is considered an important tropical and subtropical crop on the basis of its high consumption, nutritional value, and economic value to farmers [1]. Thailand is the largest producer and exporter of chili in the international market and exports to United State of America, Australia, England, Philippines, Japan, Singapore, Taiwan and the Netherlands, amongst others. In the Northeast of Thailand chili production is distributed between Nakhon Ratchasima, Loei, Chaiyaphum and Ubon Ratchathani provinces [2]. One of the most common diseases in chili plants and a lot of other tropical vegetables is anthracnose and it is caused by Colletotrichum acutatum, Simmonds ex Simmonds, C. capsici (Syd) Butl \& Bisby, C. coccodes (wallr.) Hughes and $C$. gloeosporioides Penz \& Sacc, which is widespread during the rainy season. Anthracnose is however, more conspicuous as it causes severe damage to mature fruits in the field as well as during transit and storage [3]. Control of the anthracnose disease on chili fruits still relies mainly on the use of synthetic fungicides such as Carboxin, Synap, Benomyl and Carbendaxin, etc. This may result in fungicide resistant pathogens such as those that occur in copper fungicides.

Department of Science and Mathematics, Faculty of Agro-Industrial Technology, Kalasin University. 46000, Thailand.
This means that there is an increasing need for alternative control strategies. Several research projects have shown success in the use of yeasts antagonism to control plant pathogens in chili fruits [4]. Our objectives were investigated their capabilities to control anthracnose disease caused by $C$. capsici in postharvest conditions.

\section{II.MATERIALS AND METHODS}

\section{Antagonistic yeasts}

A total 60 isolates were screened for their capabilities to control C. capsici by dual culture method. Two isolates, PFN6 and SS7 were showed high inhibition percentage up to $40 \%$. These effective isolates were kept at $4{ }^{\circ} \mathrm{C}$ on YM medium for further study.

\section{Effect of yeast cells and $C$. capsici concentration on biocontrol efficacy}

Thirty wounded chilies were used for each treatment on the biocontrol efficacy of various concentrations of antagonistic yeasts. The wounds were inoculated with $10 \mu \mathrm{l}$ of each antagonistic yeast isolate at $5 \times 10^{6}, 5 \times 10^{7}, 5 \times 10^{8}$ and $5 \times 10^{9}$ cells $/ \mathrm{ml}$ and treated with $C$. capsici at $5 \times 10^{4}, 5 \times 10^{5}$ and $5 \times 10^{6}$ spore/ml as counted by a hematocytometer. After air drying and cleaning for 1-2 h, $10 \mu \mathrm{l}$ of $C$. capsici spores/ml were added to each wound. The chili fruits were placed on plastic boxes and stored in a ventilate cabinet in the dark at $28{ }^{\circ} \mathrm{C}$ for 5 days. All treatments were measured of biocontrol efficacy and disease incidence. The data were transformed into a percentage of biocontrol efficacy $(\% \mathrm{BC}=[(\mathrm{T}-\mathrm{A}) / \mathrm{T}] \times 100$ and disease incidence $(\% \mathrm{DI}=(\mathrm{A} / \mathrm{T}) \mathrm{x} 100)$, where $\mathrm{T}$ is the number of infected wounds inoculated with $C$. capsici only, and A is the number of infected wounds inoculated with yeast antagonists and $C$. capsici.

\section{Efficacy of antagonistic yeasts in postharvest disease control on chili fruits}

Intact chili fruits (no visible wounds or scar on the surface) were surface sterilized with $0.6 \%$ sodium hyper chloride for 5 min, washed with the tap water. After air drying, chili fruits were treated with $70 \%$ ethanol. Each treatment was sprayed with $300 \mathrm{ml}$ of cell suspension $\left(5 \times 10^{8}\right.$ cells $\left./ \mathrm{ml}\right)$ and control sprayed with $300 \mathrm{ml}$ of distilled water. Chili fruits were placed on plastic boxes and kept at $28{ }^{\circ} \mathrm{C}$ for $2 \mathrm{~h}$ and followed by 
storage at $28{ }^{\circ} \mathrm{C}$ for 20 days. The percentages of chili survival in each group were recorded.

\section{Identification of antagonistic yeasts}

Antagonistic yeasts were studies morphological characteristics that according to the method described about yeast and taxonomy [5]. These isolates were identified to species by nucleotide sequencing method. The sequence of D1/D2 domain of $26 \mathrm{~S}$ rDNA was compared by BLASTn Homology.

\section{Statistical analysis}

Data analysis of disease incidence and survival percentages of chili fruits were done by using compare means with one-Way ANOVA of IBM SPSS statistics (version 19.0), SPSS Inc., Chicago, IL USA). The least significant difference (LSD) test at $P<0.05$.

\section{RESULTS}

\section{Effect of yeast cells and $C$. capsici concentration on biocontrol efficacy}

The result of antagonistic yeast to control C. capsici on chili fruits at various cell concentrations. The result shown, all isolates can reduced disease incidence when yeast cell concentration increasing and spores concentration of the pathogen were decreased. Isolates PFN6 and SS7 at $5 \times 10^{8}$ cells $/ \mathrm{ml}$ were presented high effective to control the pathogen in disease incidence than the other concentration of yeast. In addition, isolate PFN6 could be reduced the anthracnose disease more than isolate SS7 at the same concentration. Antagonistic yeast PFN6 showed highest performance to reduce the disease incidence at $37.27 \%$ when treated with the spore of the pathogen at $5 \times 10^{4}$ spores/ml. (Fig 1 and 2).

\section{Efficacy of antagonistic yeasts in postharvest disease control on chili fruits}

The antagonistic yeasts PFN6 and SS7 showed great efficacy to control mycelium of C. capsici on chili fruits at all storage times. From the result, the anthracnose disease was happened at 10 days after treated with spore of the pathogen. Isolate PFN6 showed high of survival percentage on chili fruits more than isolate SS7 in the same time. At final storage time, antagonistic yeast PFN6 had highest of the survival percentage of chili fruits at $66.25 \%$ (Table 1).

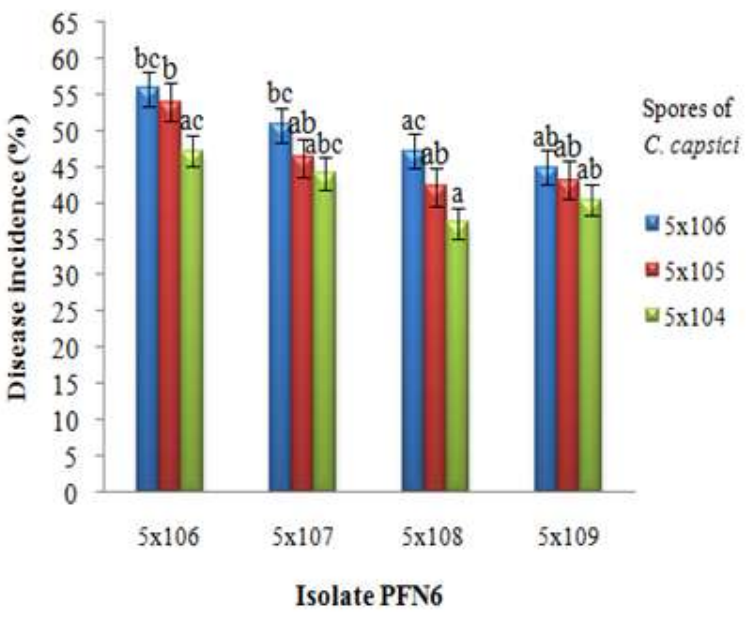

Fig 1. Disease incidence on chili fruits of yeast PFN6. Bars represented the means \pm standard error. The letters on the top of each bar indicate significant difference $(P<0.05)$.

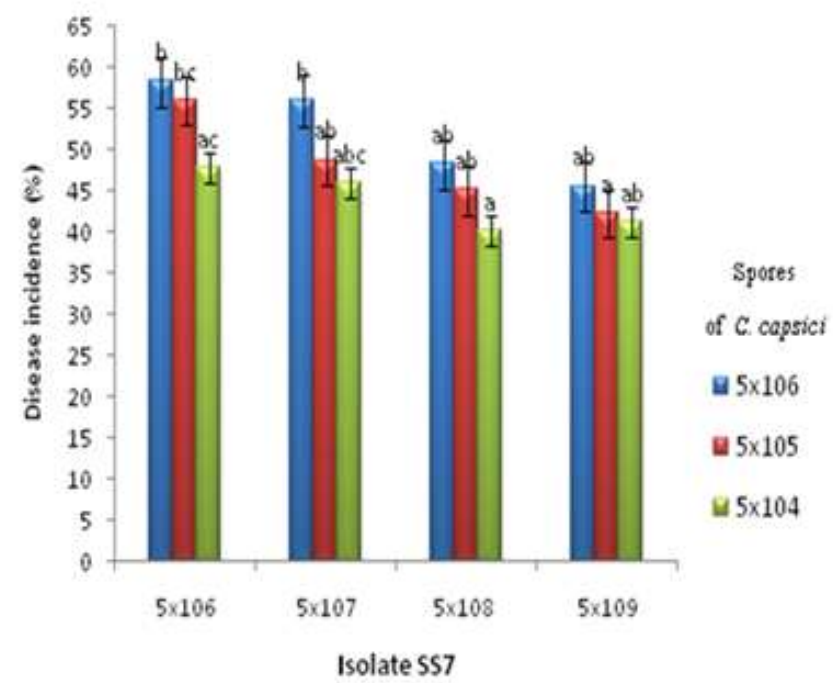

Fig 2. Disease incidence on chili fruits of yeast SS7. Bars represented the means \pm standard error. The letters on the top of each bar indicate significant difference $(P<0.05)$.

Table1 Survival Percentage Of Chili Fruits In Postharvest DISEASE CONTROL

\begin{tabular}{lcccc}
\hline \multirow{2}{*}{$\begin{array}{c}\text { Yeast } \\
\text { isolate }\end{array}$} & \multicolumn{4}{c}{ Survival of chili fruit (\%) } \\
\cline { 2 - 5 } & 5 days & 10 days & 15 days & 20 days \\
\hline PFN6 & $100 \mathrm{a}$ & $90.00 \mathrm{a}$ & $81.25 \mathrm{a}$ & $66.25 \mathrm{a}$ \\
SS7 & $100 \mathrm{a}$ & $62.50 \mathrm{~b}$ & $58.75 \mathrm{~b}$ & $43.75 \mathrm{~b}$ \\
Control & $100 \mathrm{a}$ & $6.25 \mathrm{c}$ & $0.00 \mathrm{c}$ & $0.00 \mathrm{c}$ \\
\hline$\% \mathrm{CV}$ & - & 6.63 & 8.48 & 10.32 \\
\hline The results & are & as mean & of percentage. & Value of each column \\
followed by a different & letter indicate & significant & differences \\
$(P<0.05)$ according to LSD test. &
\end{tabular}

\section{Identification of antagonistic yeasts}

The antagonistic yeasts PFN6 and SS7 were found white and smooth colony, ovoid and single or pair shape and they can produce ascospore. Each strain was analyzed for D1/D2 domain of 26s ribosomal DNA sequencing. The sequence 
analysis of yeast isolates PFN6 and SS7 showed the same species as Candida haemulonii (Table 2).

TABLE II

IDENTIFICATION OF ANTAGONISTIC YEASTS BY 26S RDNA AND MORPHOLOGICAL CHARACTERISTICS.

\begin{tabular}{|c|c|c|c|c|c|c|}
\hline $\begin{array}{l}\text { Yant } \\
\text { yein }\end{array}$ & $\frac{150}{60}$ & 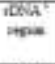 & Species & $\begin{array}{l}\text { Celony } \\
\text { morphology }\end{array}$ & $\begin{array}{c}\text { Cell } \\
\text { morphology }\end{array}$ & $\begin{array}{c}\text { Type } \\
\text { of spore }\end{array}$ \\
\hline PFNG & 100 & DID2 & $\begin{array}{l}\text { Camdidat } \\
\text { haemmalanif }\end{array}$ & $\begin{array}{l}\text { White, laght } \\
\text { beige, } \\
\text { smooth and } \\
\text { buryrous }\end{array}$ & $\begin{array}{l}\text { ovood. } \\
\text { ellipsoidal } \\
\text { (2-7x2-7 um) } \\
\text { single or pairs }\end{array}$ & Ascospore \\
\hline 537 & 100 & D1D2 & $\begin{array}{l}\text { Candida } \\
\text { haemulanif }\end{array}$ & $\begin{array}{l}\text { White, light } \\
\text { beige, } \\
\text { smooth and } \\
\text { butyrous: }\end{array}$ & $\begin{array}{l}\text { ovoid, } \\
\text { ellipsoidal } \\
(2-7 \times 2-7 \mathrm{~mm}) \text {. } \\
\text { single or pairs }\end{array}$ & Ascospore \\
\hline
\end{tabular}

\section{CONCLUSION AND DISCUSSION}

The antagonistic yeasts PFN6 and SS7 have been successfully identified Candida haemulonii by using 26S ribosomal DNA. Both strains were presented the morphological characteristic similarly Candida haemulonii Type II (Van Uden\&Kolipinski) S.A. Meyer\&Yarrow that located at Metschnikowia clade [6]. These antagonistic yeasts can control C. capsici mycelium in disease incidence and postharvest disease control on chili fruits. Several antagonistic yeasts in Candida have previously been used as biocontrol agents to control the anthracnose disease caused by $C$. capsici in postharvest crops such as $C$. tropicalis, $C$. famata and $C$. membranifaciens $[7 ; 8]$. However, there is no report on use of C. haemulonii to control C. capsici in chili fruits. These studies presented the first evidence of antagonistic yeast $C$. haemulonii to control anthracnose disease. This strain can reduced disease incidence and can preserved chili fruits from the pathogen at 20 days. From the result of disease incidence of $C$. haemulonii shown as $37.27 \%$. This efficacy is similar with the studies of [9] used yeasts $C$. musae R6 and $C$. quercitrusa $\mathrm{L} 2$ to control C. capsici on chili fruits showed the disease incidence at $6.70 \%$ and $33.60 \%$ respectively. Yeast PFN6 demonstrated great action to inhibition the pathogen mycelium in postharvest disease control. The result in survival percentage of chili fruits of this strain was showed at $66.25 \%$ and $43.75 \%$ at 20 days. This investigated that the antagonistic yeast $C$. haemulonii had efficacy to control anthracnose disease over than 20 days. This result indicated the mode of action involes space and nutrient competition and lytic enzyme action. Because of, the antagonistic yeast can rapidly growth more than $C$. capsici mycelium, so, yeast can compete the nutrient and space from the pathogen as a result in eventually death of the pathogen. In addition, the yeast cell produce lytic enzymes such as chitinase and $\beta-1,3$-glucanase that could enhance the attaching ability of yeast to hyphae of the pathogen [10]. This finding provide a powerful stimulant for development of the yeast $C$. haemulonii as an alternative to control anthracnose disease caused by $C$. capsici in chili fruit.
Nevertheless, more studies including field trails need to be performed.

\section{V.ACKNOWLEDGEMENTS}

I would like to thanks Kalasin University for supported research funding, thanks to Microbiology Department, Faculty of Science, Khon Kaen University for supported special research apparatus and very thanks to Prof. Dr. Wandee Bunyatratchata for good suggestion to complete research.

\section{REFERENCES}

[1] Muthukumar, A., Eswaran, A., Nakkeeran, S. and Sangeetha, G. 2010. Efficacy of plant extracts and biocontrol agents againt Phytium aphanidermatum inciting chili dumping-off. Crop Protection. 29: 14831488. http://dx.doi.org/10.1016/j.cropro.2010.08.009

[2] Narongrit, W. 2007. Chilli production practices and pesticide application behaviors of chilli grower in important areas in the Northeast region. Master of Science, Thesis in Agricultural Extension, Graduate School, Khon Kaen University, Khon Kaen.

[3] Chanchaichaovivat, A. 2008. Using hand on Yeast biological control for Colletotrichum capsici to teach organism interrelationship concepts and encourage critical thinking. The degree of Doctor of Philosophy (Science and Technology), Faculty of Graduates studies, Mahidol University.

[4] Druvefors, U. A. 2004. Yeast biocontrol of grain spoilage moulds: Mode of action of Pichia anomala. Doctoral thesis, Swedish University of Agriculture Science. Uppsala. 44 p.

[5] Kurtzman, C. P. and Fell, J. W. 1998. The Yeast : A Taxonomic Study. 4th edition. Elsevier, UK.

[6] Kurtzman, C. P. and Fell, J. W. 2011. The Yeast : A Taxonomic Study Volume 2. 5th edition. Elsevier, UK.

[7] Fard, F. A., Etebarian, H. R. and Sahebani, N. 2012. Biological control of gray mold of apple by Candida membranifaciens, Rhodotorula mucilaginosa and Pichia guilliermondii. Iran. J. Plant Path. 48(1): 1726.

[8] Demicri, F. 2011. Effects of Pseudumonas fluorescens and Candida famata on blue mould of citrus caused by Penicillium italicum. Australian journal of crop science. 5(3): 344-349.

[9] Chanchaichaovivat, A., Pintip, C. R. and Bhinyo, P. 2007. Screening and identification of yeast strains from fruits and vegetables: Potential for biological control of postharvest chili anthracnose (Colletotrichum capsici). Biological Control. 42: 326-335.

http://dx.doi.org/10.1016/j.biocontrol.2007.05.016

[10] Wisniewski, M., Biles, C., Droby, S., McLaughlin, R., Wilson, C. and Chalutz, E. 1991. Mode of action of the postharvest biocontrol yeast, Pichia guilliermondii, I characterization of attachment to Botrytis cinerea. Physiological and Molecular PlantPathology. 39: 245-258. http://dx.doi.org/10.1016/0885-5765(91)90033-E

Punika Chaisemsaeng,, I was born at Roi Et province, Thailand. I finished Bachelor and Master Degrees from Biology Department, Faculty of Science, Khon Kaen University, Thailand. I finished Doctor of Philosophy from Microbiology Department, Faculty of Science, Khon Kaen University, Thailand. A lecturer on microbiology at Kalasin University, Kalasin province, Thailand. Major field are biocontrol by yeasts and characterization of chitinase gene expression, regulation of chitinase enzyme. 